[Author's Accepted Manuscript. Published in J Global Responsibility 2019.

https://doi.org/10.1108/JGR-11-2018-0075 ]

\title{
The future of work: disciplined useful activity
}

\author{
Alan Cottey \\ School of Chemistry, University of East Anglia, Norwich, NR4 7TJ, UK
}

\begin{abstract}
Purpose - The purpose of this paper is to draw attention to the importance of the current global ecological overload (GEO) for the future of work in the $21^{\text {st }}$ century and to propose a new understanding of what work is.
\end{abstract}

Design/methodology/approach - To achieve this purpose, the author uses qualitative methods to assess what is likely and what is possible. He presents three broadbrush future scenarios, dubbed chaos, muddle and wisdom. The approach adopted depends on two basic normative principles, named Liveable Global Habitat and Necessities as of Right.

Findings -The neoliberal commitment to economic growth is a driver for GEO. A liveable future requires a decisive turn away from neoliberal values. As part of this, the author proposes a new understanding of work, disciplined useful activity, which differs radically from the current understanding. 'Useful' means contributing to two basic principles, (1) to maintain and enhance a civilised human society and a liveable global habitat for a rich variety of species, (2) to accord to all people, as of right, in practice and not merely in name, the basic necessities of a civilised life.

Social implications - Al and robots will probably continue to replace today's kinds of human employment. But this need not render any humans unemployed, whose work (in the new sense) will be wanted in, for two examples, caring (including self-care) and participatory democracy.

Originality/value - This paper offers a contribution to the resolution of the current and anticipated problems of GEO and of disruptive technologies. 


\section{Introduction}

An argument about the long-term future of work is developed, starting from the reality of current multiple stresses on the Earth's ecology (Rockström et al., 2009). These stresses, taken together, are here called global ecological overload (GEO). It is noted that political responses to GEO are insufficient (McNeill and Engelke, 2014), so that the outlook for the rest of this century is bleak. It is nevertheless argued that denial, inattention, despair and fatalism only increase the likelihood of an ecological catastrophe (Norgaard, 2011), and that a wide-ranging search for positive solutions is required.

The future of work is associated with this great ecological issue because the current conception of work (roughly - remunerated employment) is closely linked with economic growth (Schwab et al. 2017). The linkage is explained as the argument of the present paper proceeds. A re-appraisal of what work is, when it is useful and when it is harmful, is presented. The proposed new meaning of work is disciplined useful activity, with useful meaning the advancement of two basic value-laden principles, named Liveable Global Habitat and Necessities as of Right. This understanding of work is similar to that used by Alfred Marshall - "We may define labour as any exertion of mind or body undergone partly or wholly with a view to some good other than the pleasure derived directly from the work", p 54 of Marshall ([1920] 1961).

\section{An uncertain future}

Considering the future of work on the scale of several, or even many, decades is a hazardous undertaking. It is wise to avoid prophecies (definite, literal and unqualified predictions), characterised by George Eliot as the most gratuitous of mistakes (Eliot, [1871-2] 1965). Yet conscious planning of projects is a ubiquitous and essential part of human activity. Projects taking a few years and similar to those done before can be completed more-or-less as planned. But the future of work (in its widely used sense of wage labour or remunerative self-employment) over the remaining fourfifths of the current century is qualitatively uncertain. There are two outstanding sources of uncertainty - global ecological overload and disruptive techniques. 'Techniques' is used here in a more general sense than technology and includes 
social innovations. The sources of concern and uncertainty extend beyond such issues of special topical interest as automation, robotics and Al.

\section{Global ecological overload (GEO)}

Although the question of job losses is the focus of a great deal of concern about the future of work - see for example Maitland and Thomson (2014) or West (2018) - it is argued that there is another, even more important, source of concern and uncertainty about the future of work, namely global ecological overload. Rockström et al. (2009) identify nine global biophysical thresholds, all influenced significantly by human actions, beyond which lie disastrous consequences. Three of these thresholds, biodiversity loss, climate change and interference with the nitrogen cycle have already been crossed. In a major review, Sánchez-Bayo and Wyckhuys (2019) report an alarmingly rapid decline of insect populations and diversity.

Several aspects of GEO, notably climate change, have now become widely known and accepted but acceptance of these problems has not yet led on to effective collective action. International efforts in Kyoto 1998 to agree meaningful reductions in greenhouse gas emissions (United Nations 1998) have failed and been replaced in Paris 2015 by weak statements of intention (Milman, 2015). Even these do not have full international support. And few among the states whose rhetoric is positive are at present on schedule with actual reductions. Meanwhile the 8 October 2018 IPCC Special Report 'Global Warming of $1.5^{\circ} \mathrm{C}$ ' (Intergovernmental Panel on Climate Change, 2018) continues the gradual firming-up of earlier cautious IPCC conclusions. Despite the warnings from these and many other authors, economic growth - the root of the problem - is still pursued vigorously (McNeill and Engelke, 2014).

\section{Growth imperative}

After the destruction and horror of the Second World War there was a strong desire to build a better world. Economic growth was rapid and seemed unproblematic. This period of reconstructive growth and reduced inequality came to an end in the 1970s. The onset of low growth and high inflation (stagflation) produced a reaction against the Keynesian economics which had dominated since the war. This was an opportunity that advocates of neoliberalism - a supposedly free market with weak 
regulation - exploited fully (Harvey, 2005). Since then it has occupied the centreground of economics, states, business, finance and common language.

As a broad generalisation, one may say that it appears that most professional economists continue to stand in that centre ground and take the view that long-term growth is possible, acceptable and indeed vitally necessary. The issue of pollution is considered solvable by innovation (new clean industries) and resource shortage by substitution. Economists' commitment to growth and to minor changes away from the present economic trend is separated by a wide gulf from the perceptions of those who come to the problems from an environmental or ecological standpoint. The latter emphasise the severity of the global ecological problems, the inadequacy of human response to date and the urgent need for decisive change from the course that has been followed during the last several decades. Evidence for this overview may found at numerous places. For the 'economics take', see for example The World Bank (2004), Weil (2013); for the 'ecology take', see Costanza et al. (2015), Scott Cato (2011), Simms (2013). Further evidence for the wide gulf may be found by comparing the business and environment reports in the news media.

It is here argued that, with ever more sophisticated machines replacing most remunerated human work (as currently understood), the present economic trend is problematic, for a large part of the fruits of that work are concentrated as private property in very few hands (UBS/PWC, 2018; Credit Suisse Research Institute, 2017; Credit Suisse, 2018). The trend is dysfunctional. It relies on continued rapid growth beyond planetary boundaries in an attempt to create enough remunerated work for humans. It amplifies consumerism, creates unrealisable expectations and fragments society into mutually hostile sectors, some resentful (Carstarphen, 2017), some jittery (Spencer, 2018). If there is no major change of direction, the result appears likely to be a descent into chaos.

Capitalism has in the past adapted to many new situations (Alexander, 1998). It has for a couple of decades been adapting significantly to GEO by the introduction of solar and wind energy (Peake, 2018), the use of IT (Elliot, 2011) and the transition to a knowledge economy (Peters, 2011). Nevertheless, the introduction is too slow and the breadth of change too restricted, so that the overload continues to increase. See, 
for example, Earth System Research Laboratory (2019) for data showing the still accelerating concentration of carbon dioxide in the Earth's atmosphere. It is hard to think of a set of adaptations that retain the two central features (rapid growth, weak regulation) of neoliberalism and prevent the kind of perfect storm (severe climate change, overpopulation of humans, loss of other species' habitat, extreme strife) envisaged by Beddington (2009).

\section{A stark choice}

The ecological view is that humanity faces a stark choice: continue on the present trajectory, rapidly emitting greenhouse gases (Intergovernmental Panel on Climate Change, 2018), destroying habitats, polluting oceans, etc, in a downward spiral of violence; or turn decisively from the deregulation and growth ideology to a sustainable one. The second route is of course preferable, but widely held and deeply embedded economic and political values (The World Bank, 2004) stand in the way of a decisive turn. These values include - prioritisation of private property, acceptance of unlimited accumulation, distrust of society, belief that self-interest produces the best net result through the operation of a (supposedly) free market, neglect of what is not measurable in economic terms, and reduction of collective (governmental) powers especially regulation (Harvey, 2005). These values now dominate human activity to the point of being invisible to many and thus hard to question.

\section{Liveable Global Habitat and Necessities as of Right}

All hopes, actions and plans are based on underlying values. The relevant values underpinning the analysis and ideas of the present paper can be expressed in two principles -

(1) Liveable Global Habitat: to maintain and enhance a civilised human society and a liveable global habitat for a rich variety of species

(2) Necessities as of Right: to accord to all people as of right, in practice and not merely in name, the basic necessities of a civilised life.

If humanity would act in closer accordance with these principles there is a good chance of slowing, arresting and reversing GEO. The relevance of the second principle is that if everyone could be confident of the necessities of a civilised life 
many of today's unsustainable practices would become unnecessary and unattractive. For the currently impoverished, harmful practices like the desperate and unsustainable search for firewood could be avoided. For those who are prospering but insecure, the assumption that more is always good could give way to 'enough is enough'.

\section{Rising to the occasion}

Society - people, leaders and institutions - has, so far, failed to rise to the occasion presented by GEO. The problem is indeed hard to come to grips with. The spatial and temporal scales are beyond what normally stirs individuals and institutions into meaningful action. And that being so, political leaders, of whatever stripe, also fail to act meaningfully. So, is there no hope?

One response to-this question is that although the outlook is bleak, failure is not certain. There are some reasons for hope. There has been and still is bold vision from thinkers who imagine an economics that prioritises cooperation and recognition of limits: a few examples are - Dietz and O'Neill (2013), Scott Cato (2011), Simms (2013).

Critics of neoliberal economics may also note that its pioneers, notably Friedrich Hayek, spent several decades in the margins (Srnicek and Williams, 2016) before storming the world in the 1980s. Such is the nature of most radical changes. This is demonstrated by the struggles for progressive change of behaviour on more specialised, less grand, issues. The Rapid Transition Alliance (2018) has produced a report on current knowledge of rapid behaviour change, with numerous examples. In these cases rapid progress occurred as breakthroughs following resolute, protracted researches and campaigns from the margins of mainstream thought.

\section{Scenarios: chaos; muddle; wisdom}

Growth of the current kind, monetised and weakly regulated, is already destructive on a global scale and attempts to prolong it in the same form accelerate the ecological destruction (Credit Suisse Research Institute, 2017). Such growth cannot continue. Of a practically infinite number of imaginable future scenarios, three broad outlines are here described. 
Chaos: humanity may try to continue with minimal adjustment. Stresses on the global ecology rise rapidly. Human strife increases and overwhelms the institutions of civilisation, such as diplomacy and law.

Muddle: there may be a partly managed adaptation of the current kind of economic growth, with machines doing most of what is currently known as work, and humanity muddling along with a high level of inequality between a few who own the machines and the rest who are dependent.

Wisdom: growth as it is now understood (economic growth) may be transformed into growth of a qualitatively different kind - cultural growth, meaning a growth in maturity, wisdom and understanding of the global ecological crisis (Maxwell, 2007). Such a transformation involves a profound change of values, notably from competitive to cooperative and from 'never enough' to 'enough' (Dietz and O'Neill 2013). This scenario assumes that the new values find expression in appropriate actions to correct the ecological imbalances that have been built up. In particular, it is not enough to reduce net emissions of greenhouse gases. Significant drawdown of them is necessary and possible (Hawken, 2017). For an overview on degrowth (décroissance, reduction), with many references, see Demaria et al. (2013). The 'need, entitlement, desert' framework for discussing the justice of degrowth measures is discussed in Gabriel and Bond (2019).

Consonant with George Eliot's stricture, prophecies (firm predictions) are not made in the present article. But action of one kind or another is unavoidable and effective actions require pre-planning, based on estimated probabilities. From the history of the last few decades, it may be considered by some that the chaos scenario is probable, that the muddle scenario has a moderate probability and that the wisdom scenario is quite unlikely. Even with such a grim assessment, however, the wisdom scenario is worth aiming for.

Most discussions of plans for the future are short-term and assume at most small changes from current trends, yet the future is radically uncertain. The components of GEO have long lead times. They may be expected to become more obvious and the 
defects of a weakly regulated market economy expected to become more clearly recognised. See Pearse (2018) on the failure of carbon pricing as a means of reducing CO2 emissions. See Hall and Soskice (2001) for discussion of the distinction between liberal and coordinated market economies. If focused determined attention is applied, humanity may belatedly free itself from the weak regulation mindset and open itself to many ideas in the wisdom scenario.

At this point it is perhaps prudent to rebut explicitly the common charge that radical proposals have an intolerant character and risk leading to totalitarianism. The ideas presented here are focused on the dangers of GEO and are open-minded in other respects. They are neutral in respect of the secular/sacred and spiritual/materialistic binaries. They are consistent with various juridical, legislative and governmental systems. They could be compatible, in some areas, such as the arts, with a high degree of individualism. There could be a relatively free market, within the overriding constraints set by the requirements of sustainability.

Thinking about qualitative change means recognising that a great prize is worth striving for, even if the path may be rocky and success far from assured. The human responses may at present be inadequate, leading in the chaos or muddle directions but they need not remain so. The needed qualitative change includes a radical reevaluation of the concept of work.

\section{Many meanings of work}

According to p.2 of Dejours et al. (2018) "One might think - given the palpable and widespread concerns that gravitate around work and the difficulties we have in comprehending them - that philosophers, social theorists, and other theorists in the humanities would have had much to say on the subject. ... But that is not the case." Of the relatively small academic output with a broad conception of work, Beyond employment (Offe and Heinze, 1992) and The brave new world of work (Beck, 2000) are of special interest. Of the utopian literature, the vision of a cooperative society in News from Nowhere (Morris, [1891] 2003) can still inspire, if the sentimental view of the Middle Ages and the inconsistent attitude to technology can be overlooked. 
The word 'work' and its compounds have an enormous range of meanings and resonances, as may be seen from the long entry 'work' in the online Oxford English Dictionary (n.d.). But even this does not capture some of the peculiarities of past and current usage. Current discourse on work is not simply about getting something useful done. Work has long been considered virtuous in its own right (Swan, 2016). Minimising work is often considered to be errant, or worse. Everyone is expected to work, except infants and pensioners, who are said not to work. School age children are compelled to work. Further and higher education have a pseudo-compulsory character - many students are funnelled into tertiary education, having few attractive alternatives.

Work is often formalised, beyond the practical requirements of getting something useful done. What does not fit the template is not counted (Offe and Heinze, 1992). For example, unpaid caring for children does not count in quantitative economic measures, so those who perform this important work are deemed economically inactive. It is better for the economy if those parents and others engage in paid employment elsewhere and recycle part of their income in paying wage-earners to care for the children. Many of these peculiarities are a consequence of deepening economism - the capture by formal economic language of large swathes of discourse in areas of culture that formerly were discussed in personal, human, moral or religious terms. This trend, initiated at the transition from feudalism to capitalism, has been intensified in the neoliberal period (Harvey, 2005). Political discourse, including media reports to the general public, is conducted mainly within the frame of neoliberal economics (Cottey, 2018a). This economic language focuses on a few measurable but simplistic numbers (example - GDP) and ignores what cannot readily be reduced to numbers (example - housework). For critiques of such language, see Earle, Moran and Ward-Perkins (2017) and Lanchester (2014). For a critique of the self-serving usages 'value creation' and 'wealth creation', see Mazzucato (2018). Numerous indicators of activity or of well-being, transcending the limitations of GDP, have however been proposed, especially in the last few decades. Some alternative measures are reviewed briefly in Commission of the European Communities (2009). 
The rapid replacement of one or another kind of heavy slow human labour by ingenious efficient techniques is a constant feature of recent centuries (Vleuten et al., 2017). Significant new technologies are disruptive. They disrupt not merely an earlier technology, which is no great problem, they generally disrupt livelihoods and ways of life. When important new technology appears in a laissez-faire political setting, the results in the transition period can be brutal. Such was the case for the Industrial Revolution in England (Fielden, 1969). There followed a period of adaptation and reform (Henriques, 1971). British manufacturing was able to expand into large markets, at home and abroad, and the growth absorbed the greatly increased production, so that mass unemployment was generally avoided.

The 1950s saw heightened interest in automation and robots (Woirol, 1996). The post-WWII period was a time of belief in planning and social democracy and it was anticipated that the robots would relieve people of repetitive labour and usher in an age of short working hours together with the prosperity to enjoy leisure (Neumeyer and Neumeyer, 1958). Progress along these lines did indeed occur in the richest social-democratic countries. The enhanced productivity of new techniques, as in the 19th century, went partly into reduced working hours but more into increased production (McNeill and Engelke, 2014), a consequence of capitalism's priority - to maximise owners' returns.

Now, there is again concern about disruptive effects - from artificial intelligence (AI) and robotics (Boyd and Holton, 2018). Neoliberalism advocates minimal intervention by nation-states into the (supposedly free) market (pp. 21-22 of Harvey, 2005). To the obvious question 'what will happen to the unemployed workers?', the neoliberal reply is - the market will provide new jobs by virtue of economic growth. New jobs were indeed created in large numbers in the neoliberal historical period - four decades from the late 1970s. That period now appears to be at an end, as the extent and effects of GEO (Rockström et al., 2009; Sánchez-Bayo and Wyckhuys, 2019) become more obvious and populist unrest arises in many parts of the world (Galston et al., 2018).

\section{Work now}


There is a great difference between disciplined useful activity and today's understanding of 'work'. (See Illich (1978) for a thought-provoking, if rhetorical, expression of ideas having elements in common with those discussed here.) A large group of current usages of the word coalesce around paid labour or remunerative self-employment or compulsory unpaid labour or quasi-compulsory labour. The utility and the remuneration of work are poorly correlated. While much important work, notably domestic work, is unpaid and does not count in economic discourse, a significant part of remunerated work is not useful, and some indeed has a net harmful effect.

Nevertheless, every area of work has a useful core. What this means depends on the values of a culture. Here, the meaning is informed by the two principles, namely 'to maintain and enhance a civilised human society and a liveable global habitat for a rich variety of species' and 'to accord to all people as of right, in practice and not merely in name, the basic necessities of a civilised life'. In this way an individual or a group can attempt to clarify, as best it can, what is useful work, what is not useful and what is harmful. Even when the two principles, or something like them, are accepted a division of this kind is necessarily subjective and has fuzzy boundaries. There are significant differences of opinion even within one culture. Nevertheless it is here claimed that GEO is an overarching condition of human life today and this permits some general observations on the degree to which various kinds of work are useful or not, and beneficial or harmful.

In many kinds of work the useful core is surrounded by accretions that have other purposes. These purposes may have rational explanations but they do not advance the core purpose and they may impede it. The accretions are espoused by those who benefit thereby, but are justifiable only in a partisan way. They fail to be truly useful by failing to advance the Liveable Global Habitat and the Necessities as of Right principles.

The accretions are of two main types - defensive and expansive. The defensive kind of work is typified by the defence of established industries which have become harmful through changed conditions. The most notable examples in the present times are the fossil fuel industries. Employees and owners (including shareholders) 
can have a great deal invested in such an industry. For them, accepting that the work done has turned from net-useful to net-harmful is difficult, extremely so if their livelihoods are on the line. Seen within a big frame, extracting and burning fossil fuels can now be justified only in strictly limited amounts for high-priority purposes. It must be drastically and rapidly reduced, if descent into chaos is to be avoided (Intergovernmental Panel on Climate Change, 2018). It is however important to understand the position of the defenders of the status quo. Constructive discussions about positive, attractive alternatives are needed (Hawken, 2017).

The other kind of accretion around useful work, the expansive, is harmful when expansion exceeds what is compatible with the two principles. In today's world economy, expansion (growth) is pervasive. Competition is fundamental and the alternative to growth is death. Consequently, much remunerated work is directed towards growth and employment for their own sakes (Robbins, 2018). This priority is maintained even when the results, observed from a non-partisan point of view, are evidently contributing heavily to GEO. Businesses and many services, such as education, not formerly operating under highly competitive conditions, now spend a considerable fraction of their resources, including workers' time, in promoting their public image, in competing against rivals and in fundraising (Wilson et al., 2018). This effort takes away from their core, useful activity. From data reported by Statista (2018), global advertising spending was US\$520bn in 2016 and rose 4\% p.a. between 2010 and 2016.

Accountancy, auditing and law are vital elements of a complex civilised society. Yet their core contributions to the two principles are diluted as their services are directed to minimal compliance with, and manipulation of, increasingly complex tax and regulation regimes (Hung and Cheng, 2018). Excessive competition also reduces trust, which underpins the cooperation needed in any non-trivial undertakings and especially in complex ones. Further, the current level and quality of competition is harmful by contributing to the growth imperative that has already taken global economic activity beyond planetary boundaries (Rockström et al., 2009; Grooten and Almond, 2018).

\section{Work as disciplined useful activity}


A YouGov report (Dahlgreen, 2015) found that over one-third of British workers considered their jobs to be meaningless. The current and near-future form of automation, often conceptualised as $\mathrm{Al}$ and robotics, is capable of displacing a large fraction of human labour as it now is, including skilled and professional work (Susskind and Susskind, 2015). What happens to people then? Contrary to most expectations, it is here suggested that there will be much to be done but it is very different from what has hitherto been generally regarded as work. In the light of the discussion so far, a new usage of the word 'work' is proposed, namely as disciplined useful activity. Here 'useful' means contributing to the realisation of the Liveable Global Habitat and Necessities as of Right principles. This implies profound changes in what is needed from humans by way of work and in what motivates people to perform work in this new sense.

\section{Who and what does what?}

Making full use of everything that $\mathrm{Al}$ and robotics can do, by way of production, physical organisation (maintenance, repairing, tidying and cleaning) and bureaucratic organisation (including much professional work currently performed in accountancy, education, law, public relations, etc), would amount to a radical encroachment on work as it is now understood. "[l]t's no longer pure science fiction to contemplate completely automated mines, farms, factories, and logistics networks supplying all the food and manufactured goods a population could require. Many service jobs and much knowledge work could also be automated" (Brynjolfsson and McAfee 2015). If conventional economic growth is no longer acceptable, there appears at first sight to be little left for humans to do; work for some people with special talents, to be sure, but what about the rest? Is there to be, at last, the age of leisure that in the $1950 \mathrm{~s}$ was expected? Are some people to be merely tolerated and supported by the productivity of new techniques and the work of an elite?

A new answer is here proposed. Turning away from the destructive ideas of the present time, repairing the damage done, internalising constructive values and putting them into practice - all this calls for sufficient work (in the new sense) for everyone. This is not special work which only a vanguard can do. A new kind of work is needed from everyone willing. Of the work that is useful, in the sense of advancing the two principles, a great part can be classed as caring. Today, caring commonly 
refers to caring for others in need of special care - young, old, sick and disabled people. It is here suggested that caring can be interpreted more broadly and includes domestic work (housework and DIY) and self-care. These are, after all, fundamental requirements for the continuation of life and its maintenance at a high standard.

Another major type of useful work is political in its general sense of contributing to the polis - becoming informed, thinking, discussing, deciding and acting on what is to be done in the public sphere. An important segment of such work is conflict resolution. Conflicts of interest occur everywhere and all the time. They cannot be eliminated. The best to be realistically aimed at is an ethos in which a person sees herself or himself at the centre of concentric circles, with nearest being dearest, but altruism having a global reach. In a wisdom scenario, conflicts of interest would generally be admitted and addressed in a constructive manner (Barash and Webel, 2018). Humanity's rise to the occasion, from the confused and angry conditions of today, demands a great deal of hard work, although of a kind very different from what is now thought of as work and considered worthy of remuneration.

Work, rest and play

A few words are needed on why the new concept is described as disciplined useful activity. The concept is far broader than what is commonly thought of as work but not as broad as any useful activity. The usual idea of work carries a strong element of discipline. Most workers are to a great extent required to be doing prescribed actions at the right time in the right manner in the right attire. Some of this discipline relates to social power relationships but some of it is needed for efficiently achieving the goals of the work. The concept of work as disciplined useful activity includes much everyday activity that is not counted in the current understanding of work, including much of domestic life and self-care. Domestic tasks, public interest actions and selfcare that need to be done properly and at the right time, do count as work. Yet it would be extending traditional usage too far to include as work casual activities that may happen to be useful. Random acts of kindness do not count as work. Likewise, rest and play, although important for maintaining life and its quality, do not count as work.

\section{Necessities as of right}


If, after becoming manifestly dysfunctional, the growth trend is rejected, the efficient production and organisation of goods could become an opportunity rather than an ever worsening crisis. The wasteful aspects of competition which lead to selfdestructive overconsumption could be avoided. Efficient production and organisation could contribute to the implementation of the Necessities as of Right principle - to accord to all people, as of right, in practice and not merely in name, the basic necessities of a civilised life.

There exists a long-standing class of proposals in this direction, which have in recent decades been entering mainstream discourse, namely proposals around the phrase Universal Basic Income (UBI) (Sloman, 2018). In the present article, something more general than UBI is proposed. The delivery of the basic necessities of a civilised life is more than a set of monetary transactions. Indeed, during the decades after the second world war, a number of jurisdictions delivered two of the most important of those necessities - elementary education and basic healthcare - in a largely nonpecuniary manner (Modi et al., 2018). In the last few decades, however, the nonpecuniary nature of these deliveries has been eroded by monetising tendencies (Bhopal and Shain, 2014).

Neoliberal market fundamentalism is here rejected as leading to extremes of concentration of power and ownership (Credit Suisse, 2018), destructive growth (McNeill and Engelke, 2014) and neglect of those in need of help (Harvey, 2005). Cultures that respected the two principles could however retain elements of the traditional market philosophy. This could for example include an extensive but not ubiquitous use of money in fair and efficient transactions.

\section{Incentives to work}

In a kinder economy of the future, two issues must be addressed - the existence of some freeloaders (people taking UBI and contributing nothing to society) (Alexander, 2015) and the fiscal problem (a jurisdiction's inability to collect enough tax to pay for UBI and other necessary services) (Alexander, 2015). The speed and skill of the techniques of the future permit the resolution of both of these issues but it does require that the basic income be sufficient to deliver the necessities while leaving incentives for those so inclined to take on remunerated work. From the results of 
several trials of UBI (p. 23 and pp. 184-186 of Dyer, 2018) by far the greater number of people in a potential workforce choose to supplement their basic income with remunerated work. The monetary cost of UBI may then be found from taxation income tax and sales tax. The question 'can UBI be afforded?' is often asked but only in the context of an economy approximately as it is now. In a wisdom scenario, however, radical change has occurred, whether by human design or force of circumstance (consequences of GEO). Production of goods and services would be sufficient and not excessive, and justly distributed. Moreover, the considerable amount of human effort currently directed at maintaining unjust social relationships would be largely a thing of the past. In such a scenario, a pecuniary system like UBI would be, in the wider economy, a significantly smaller factor than is currently envisaged. In times of economic hardship the UBI would be spartan (but still providing necessities) and the sales and earned income taxes would be relatively high. Such a society would be better than one with paupers and plutocrats.

A limit to accumulation (Alexander, 2015; Cottey, 2014; Pizzigati, 2018) would also be useful, to prevent excessively concentrated ownership. There is enough flexibility in these ideas to allow the creation of a just economy, one that would avoid most of today's harmful effects and permit the healing of the ecological scars of recent times.

\section{A new attitude to work}

By virtue of $\mathrm{UBI}$, personal autonomy in relation to the new concept of work would be deeper and more widespread than at present. The current attitude to work held by most people, that it is a chore performed under threat of poverty, would no longer be normal. The component of work that is self-care and care for others would be performed naturally, with less stress than exists at present. Since machines would be performing most of the required routine productive and organisational tasks (Brynjolfsson and McAfee 2015), people would have considerably more energy and creativity than at present to devote voluntarily to the vital tasks of correcting the GEO. Activities that would continue or exacerbate GEO would be inhibited by the cooperative and satiable values of the wisdom scenario. If humanity fails to adapt, the likely consequence is extension of the current muddle leading on to chaos.

\section{Practice, management and leadership}


One may divide the roles taken by workers into three categories - the practitioner role, the manager role and the leader role. 'Practitioner' here means anyone who performs directly a task (a piece of work). This classification, although designed to be appropriate to the putative future work situation, will also be recognised in relation to the traditional understanding of work roles, with the difference that practitioners are referred to simply as 'workers' or, collectively, as 'the working class'. The change of terminology reflects a more egalitarian society. There would be, however, no reduction in the need for leadership and management, due to the complexity of society, institutions and problems. The differences between work now and work in the wisdom scenario may be outlined, for practice, management and leadership in turn, as follows -

Practice: In work as it is today, most practical work (that is, just getting a prescribed short-term task done) does not allow the worker much latitude (Froissart 2006). There is little or no time for thinking about how the task fits into a larger scheme of things. Such thoughts may indeed be actively discouraged, as they may call into question the viability or morality of a larger programme or structure (Gao and Brink, 2017). In most cases the worker does the task out of need for remuneration or desire for further remuneration. In a wisdom scenario, a practitioner (practical worker), would have more freedom of thought and action, being shielded from hardship by UBI. Such workers would be able to address the great problems of the time without fear of work-related discouragement, hardship or reprisals. And with routine production and organisation performed by machines, remunerated hours could be short, leaving time for larger concerns. A wide circle of concern need not be the preserve of a minority with an unusually strong civic sense.

Management: In work as it is today, managers have more freedom than practical workers but are still narrowly constrained. In businesses, the imperative of growth "fascinates and frightens managers" (Schwab et al., 2017). In the present culture the growth imperative applies also in many other institutions, for example in government, education, health and social care. If this imperative were absent, managers would be able to focus more clearly on their central role of coordinating complex operations (Heijden, 2018). This work would, ideally, be as complex as is needed but not more so. Institutions today are ensnared in a cops-and-robbers race between regulators 
and those who work to circumvent the regulations (Naylor, 2006). The many added complexities of today's bureaucracy follow from a belief that competing self-interests are the most efficient vehicle for achieving economic success (Harvey, 2005). In the wisdom scenario, in contrast, the productivity of techniques would not be lost in wasteful competition. It would free managers to focus their talents more sharply on the coordination of projects.

Leadership: Leaders in the work situation have broad roles in society at large (Shipman et al., 2018). They relate to leaders in other institutions and some have numerous positions (Holtz, 2018). They may receive very large remunerations (Jensen and Murphy, 2004). In the interpretation of Shipman et al. (2018) high remuneration and social power go together, with leaders forming elite networks. Given the great power of such elites, are they responsible for the insufficiency, and sometimes even perversity, of responses to the most pressing problem of today, GEO? The answer offered here is - in part, but not entirely. Leaders are subject to the social conditions that contribute to their position. There is a large literature on wisdom and leadership (see for example Statler et al. (2007) and references therein) but the great issue of our time, GEO, receives scant attention. Business leaders, especially, are faced with a very disturbing challenge, being under pressure from interests incompatible with seriously addressing GEO. This may be seen, for example in the weak final paragraph of the Recommendations from the 29th World Congress on Leadership for Business Excellence and Innovation (Coulson-Thomas 2019). More can reasonably be expected of academic leaders, since academia is expected to promote new knowledge and understanding. And indeed this is the case to some extent, as witnessed by the impressive accumulation to date of knowledge of GEO and associated problems. This great programme has, however, been subjected to a sustained criticism from Maxwell (2017), who accuses academia of pursuing knowledge almost exclusively and neglecting wisdom. Nevertheless, there is some cautious movement that addresses GEO. Trencher et al. (2014) provide a review of existing initiatives which they call 'co-creation for sustainability'. They define this as "a role where the university collaborates with diverse social actors to create societal transformations with the goal of materialising sustainable development in a specific location, region or societal sub-sector." 
As an overall conclusion about leadership, it is suggested that humanity changing from its course towards chaos requires a general change of values deeper than a change in the behaviour of leaders.

\section{Rewards}

Within the expanded concept of work, remuneration would be much less important and more modest. It is vital that other rewards be ecologically benign and nontransferable. There would be many rewards for specially valuable social contributions, or for excellence in its own right. Social recognition - respect and symbolic rewards - would be relatively more important (Cottey, 2014). All such rewards reflect the deep commitment to the two principles, which replaces the current ardour for the accumulation of transferable assets.

\section{Reasons for hope}

To date, there have been some responses to the problem of GEO but they fall short of what is needed if further muddle followed by descent into chaos is to be avoided. The Paris agreement on climate change is an example (Rogelj et al., 2016) of such insufficient responses. But the future of so complex a system as the earth's ecology cannot be predicted with any degree of confidence. It is therefore rational to think about and work for a marked improvement in the overall human response. If such an outcome is to have a chance, positive thought and action are necessary. For these, hope is a precondition and, despite the daunting trends of recent times, there are some positive indications -

since bad news and especially disasters are newsworthy, some correctives in the fields of global health and economics were emphasised by the late Hans Rosling (Maxmen, 2016);

today may be a violent and dangerous time but in a per capita rating (Pinker, 2011) earlier times were worse. Thus there are some grounds for hope of future improvement;

rapid progress does sometimes occur as breakthrough following protracted campaigns. Examples are - seat-belt legislation (Rapid Transition Alliance, 2018); fall of Berlin wall (Heins, 1994). On a larger scale, an apparently 
immutable order can come to an end abruptly. The break-up of the Soviet Union in 1991 is an example (Zubok, 2007);

school strike for climate. For an up-to-date review of the international movement of school students protesting against adults' failure to respond adequately to climate change, see Wikipedia (n. d.)

\section{Conclusion}

New social developments, political or technical, start as ideas (Neville-Sington and Sington, 1993). They do not turn out exactly as conceived but they do have to be imagined in the first place. It is argued in this paper that it is worth working for something like the wisdom scenario. There is no known specific method for achieving this but the need is suggested for empathic dialogue between economic traditionalists and those advocating a profound ecological turn (Cottey 2018b). Even if the transition should be arduous and prolonged, a decisive change in this direction is possible. A good outcome does however require a great deal of work in its here proposed sense - disciplined useful activity, where useful means advancing the Liveable Global Habitat and Necessities as of Right principles.

\section{References}

Alexander, F. et al. (1998), Oxford encyclopedia of world history, Oxford University Press, Oxford.

Alexander, S. (2015), "Basic and maximum income", in D'Alisa, G., Demaria, F. and Kallis, G. (Eds), Degrowth: a vocabulary for a new era, Routledge, New York, NY, pp. 146-148.

Barash, D. P. and Webel, C. P. (2018), Peace and conflict studies, 4th edn., Sage, Thousand Oaks, CA.

Beck, U. (2000), The brave new world of work, Polity, Cambridge, UK.

Beddington, J. (2009), “The perfect storm”, Government Office for Science, 2 October 2009, 
http://webarchive.nationalarchives.gov.uk/20121212135622/http://www.bis.gov.uk/as sets/goscience/docs/p/perfect-storm-paper.pdf (accessed 21 March 2019).

Bhopal, K. and Shain, F. (2014), "Educational inclusion: towards a social justice agenda?", British Journal of Sociology of Education, Vol. 35 No. 5, pp. 645-649.

Boyd, R. and Holton, R. J. (2018), "Technology, innovation, employment and power: Does robotics and artificial intelligence really mean social transformation?", Journal of Sociology, Vol. 54 No. 3, pp. 331-345.

Brynjolfsson, E. and McAfee, A. (2015), "Will humans go the way of horses? labor in the second machine age", Foreign Affairs, Vol. 94 No. 4, pp. 8-14.

Carstarphen, M. G. et al. (2017), "Rhetoric, race, and resentment: whiteness and the new days of rage", Rhetoric Review, Vol. 36 No. 4, pp. 255-347.

Commission of the European Communities (2009), "GDP and beyond: measuring progress in a changing world", $\operatorname{COM(2009)~} 433$ final, European Union, Brussels, 20 August 2009.

Costanza, R., Cumberland, J.H., Daly, H., Goodland, R., Norgaard, R.B., Kubiszewski, I. and Franco, C. (2015), An introduction to ecological economics, 2nd edn, CRC Press, Boca Raton, FL.

Cottey, A. (2014), "Technologies, culture, work, basic income and maximum income", Al \& Society, Vol.29 No. 2, pp. 249-257.

Cottey, A. (2018a), "Economic language and economy change: with implications for cyber-physical systems", Al \& Society, Vol. 33 No. 3, pp. 323-333.

Cottey, A. (2018b), "Dialogue in critical times", Educational Philosophy and Theory, Vol. 50 No. 14, pp. 1546-1547. 
Coulson-Thomas, C. (2019), "Recommendations", 29th World Congress on Leadership for Business Excellence and Innovation, Dubai, 6th March 2019, available at https://www.academia.edu/38520212/ (accessed 21 March 2019).

Credit Suisse (2018), "Global wealth report 2018: US and China in the lead", 18 October, https://www.credit-suisse.com/corporate/en/articles/news-andexpertise/global-wealth-report-2018-us-and-china-in-the-lead-201810.html (accessed 21 March 2019).

Credit Suisse Research Institute (2017), "Global wealth report 2017: where are we ten years after the crisis?", https://www.credit-suisse.com/corporate/en/articles/newsand-expertise/global-wealth-report-2017-201711.html (accessed 21 March 2019).

Dahlgreen, W. (2015), "37\% of British workers think their jobs are meaningless", Lifestyle, August 12, https://yougov.co.uk/topics/lifestyle/articlesreports/2015/08/12/british-jobs-meaningless (accessed 21 March 2019).

Dejours, C., Deranty, J., Renault, E. and Smith, N. H. (2018), The return of work in critical theory: self, society, politics, Columbia University Press, New York, NY.

Demaria, F., Schneider, F., Sekulova, F. and Martinez-Alier, J. (2013), "What is degrowth? from an activist slogan to a social movement", Environmental Values, Vol. 22, pp. 191-215.

Dietz, R. and O'Neill, D. W. (2013), Enough is enough: building a sustainable economy in a world of finite resources, Berrett-Koehler, San Francisco, CA.

Dyer, G. (2018), Growing pains: the future of democracy (and work), Scribe, London.

Earle, J., Moran, C. and Ward-Perkins, Z. (2017), The econocracy: the perils of leaving economics to the experts, Manchester University Press, Manchester.

Earth System Research Laboratory (2019), "Trends in Atmospheric Carbon Dioxide", https://www.esrl.noaa.gov/gmd/ccgg/trends/weekly.html (accessed 21 March 2019). 
Eliot, G. ([1871-2] 1965), Middlemarch, Book 1, ch. 10, p. 110, Harmondsworth, UK.

Elliot, S. (2011), "Transdisciplinary perspectives on environmental sustainability: a resource base and framework for IT-enabled business transformation", MIS Quarterly, Vol. 35 No. 1, pp. 197-236.

Fielden, J. (1969), The curse of the factory system, Frank Cass, London (First published 1836 by A. Cobbett, London).

Froissart, C. (2006), "Escaping from under the party's thumb: a few examples of migrant workers' strivings for autonomy", Social Research, Vol. 73 No.1, pp. 197218.

Gabriel, C-A. and Bond, C. (2019), "Need, entitlement and desert: a distributive justice framework for consumption degrowth", Ecological Economics, Vol. 156, pp. 327-336.

Galston, W. A., Hunter, J. D. and Owen, J. M. (2018), Anti-pluralism: the populist threat to liberal democracy, Yale University Press, New Haven, CT.

Gao, L. and Brink, A. G. (2017), "Whistleblowing studies in accounting research: a review of experimental studies on the determinants of whistleblowing", Journal of Accounting Literature, Vol. 38, pp. 1-13.

Grooten, M. and Almond, R.E.A. (Eds) (2018), Living planet report - 2018: aiming higher. WWF, Gland, Switzerland.

Hall, P. A. and Soskice, D. (2001), Varieties of capitalism, Oxford University Press, Oxford.

Harvey, D. (2005), A brief history of neoliberalism, Oxford University Press, Oxford. 
Hawken, P. (Ed.) (2017), Drawdown: the most comprehensive plan ever proposed to reduce global warming, Penguin, New York.

Heijden, L. van der (2018), A practical guide for holistic project management, Business Expert Press, New York, NY.

Heins, C. (1994), The wall falls, Grey Seal, London.

Henriques, U. R. Q. (1971), The early factory acts and their enforcement, Historical Association, London.

Holtz, M. (2018), "Xi for life? China turns its back on collective leadership", Christian Science Monitor, 28 February, https://www.csmonitor.com/World/AsiaPacific/2018/0228/Xi-for-life-China-turns-its-back-on-collective-leadership (accessed 21 March 2019).

Hung, Y-S. and Cheng, Y-C. (2018), "The impact of information complexity on audit failures from corporate fraud: individual auditor level analysis", Asia Pacific Management Review, Vol. 23; No. 2, pp. 72-85.

Illich, I. (1978), The right to useful unemployment, Marion Boyars, London.

Intergovernmental Panel on Climate Change (2018), "Summary for Policymakers of IPCC Special Report on Global Warming of $1.5^{\circ} \mathrm{C}$ ", Geneva, 8 October 2018, https://www.ipcc.ch/sr15/chapter/summary-for-policy-makers/ (accessed 21 March 2019).

Jensen, M. C. and Murphy, K. J. (2004), "Remuneration: where we've been, how we got to here, what are the problems, and how to fix them", Negotiation, Organizations and Markets Research Paper Series, Harvard Business School NOM Research Paper No. 04-28, 12 July, Harvard University, Cambridge, MA.

Lanchester, J. (2014), How to speak money: what the money people say - and what they really mean, Faber and Faber, London. 
Maitland, A. and Thomson, P. (2014), Future work: changing organizational culture for the new world of work, 2nd edn., Palgrave MacMillan, Basingstoke, UK.

Marshall, A. ([1920] 1961), Principles of Economics, 8th edn., MacMillan, London.

Maxmen, A. (2016), "The myth buster", Nature, Vol. 540, 10 December, pp. 330-333.

Maxwell, N. (2007), From knowledge to wisdom: a revolution for science and the humanities, 2nd edn., Pentire, London.

Maxwell, N. (2017), "Can universities save us from disaster?", On the Horizon, Vol. 25 Issue 2, pp.115-130.

Mazzucato, M. (2018), The value of everything: making and taking in the global economy, Allen Lane, global.penguinrandomhouse.com .

McNeill, J. R. and Engelke, P. (2014), The great acceleration: an environmental history of the Anthropocene since 1945, Belknap, Cambridge, MA.

Milman, O. (2015), "James Hansen, father of climate change awareness, calls Paris talks 'a fraud"', The Guardian, 12 December, https://www.theguardian.com/environment/2015/dec/12/james-hansen-climatechange-paris-talks-fraud (accessed 21 March 2019).

Modi, N., Clarke, J. and McKee, M. (2018), "Health systems should be publicly funded and publicly provided", British Medical Journal, Vol. 362, article k3580, 10 September, pp. 1-4.

Morris, W. ([1891] 2003), News from nowhere, Oxford University Press, Oxford.

Naylor, R. T. (2006), "Book review. Fraud cops and bank robbers: the S\&L debacle revisited", Crime, Law \& Social Change, Vol. 45, pp. 231-239. 
Neumeyer, M. H. and Neumeyer, E. S. (1958), Leisure and recreation, Ronald Press, New York.

Neville-Sington, P. and Sington, D. (1993), Paradise dreamed: how utopian thinkers have changed the modern world, Bloomsbury, London.

Norgaard, K. M. (2011), Living in denial: climate change, emotions and everyday life, MIT Press, Cambridge, MS.

Offe, C. and Heinze, R. G. (1992), Beyond employment, Polity, Cambridge, UK.

Oxford English Dictionary (n.d.), Online Oxford English Dictionary, Oxford University Press, Oxford, http://www.oed.com (accessed 21 March 2019).

Peake, S. (2018), Renewable energy: power for a sustainable future, Oxford University Press, Oxford.

Pearse, R. (2018), Pricing carbon in Australia: contestation, the state and market failure, Routledge, New York, NY.

Peters, M. A. (2011), "Greening the knowledge economy: ecosophy, ecology and economy", Economics, Management, and Financial Markets, Vol. 6 No. 2, pp. 1138.

Pinker, S. (2011), The better angels of our nature: the decline of violence in history and its causes, Allen Lane, London.

Pizzigati, S. (2018), The case for a maximum wage, Polity, Medford, MA.

Rapid Transition Alliance (2018), "Climate and rapid behaviour change : what do we know so far?", http://www.newweather.org/wp-content/uploads/2018/09/Climate-andRapid-Behaviour-Change-Full-Report-002-1.pdf (accessed 21 March 2019). 
Robbins, M. (2018), "Looking busy: the rise of pointless jobs", The Nation, 3 December, pp. 33-35.

Rockström, J. et al. (2009), "A safe operating space for humanity", Nature, Vol. 461, 24 September, pp. 472-475.

Rogelj, J. et al. (2016), "Paris Agreement climate proposals need a boost to keep warming well below $2^{\circ} \mathrm{C} "$, Nature, Vol. 534, 30 June, pp. 631-639.

Sánchez-Bayo, F. and Wyckhuys, K. A. G. (2019), "Worldwide decline of the entomofauna: A review of its drivers", Biological Conservation, Vol. 232, April, pp. 827.

Schwab, L., Gold, S., Kunz, N. and Reiner, G. (2017), "Sustainable business growth: exploring operations decision making", Journal of Global Responsibility, Vol. 8 No. 1, pp. 83-95.

Scott Cato, M. (2011), Environment and economy, Routledge, London.

Shipman, A., Turner, B. and Edmunds, J. (2018), The new power elite: inequality, politics and greed, Anthem Press, Cambridge, UK.

Simms, A. (2013), Cancel the Apocalypse: the new path to prosperity, Abacus, London.

Sloman, P. (2018), "Universal basic income in British politics, 1918-2018: from a 'vagabond's wage' to a global debate", Journal of Social Policy, Vol. 47 No. 3, pp. 625-642.

Spencer, D. A. (2018), "Fear and hope in an age of mass automation: debating the future of work", New Technology, Work and Employment, Vol. 33 No. 1, pp. 1-12.

Srnicek, N. and Williams, A. (2016), Inventing the future: postcapitalism and a world without work, revised edn., Verso, London. 
Statista (2018), "Global advertising spending",

www.statista.com/statistics/236943/global-advertising-spending (accessed 21 March 2019).

Statler, M., Roos, J. and Victor, B. (2007), "Dear Prudence: an essay on practical wisdom in strategy making", Social Epistemology, Vol. 21 No. 2, pp. 151-167.

Susskind, R. and Susskind, D. (2015), The future of the professions: how technology will transform the work of human experts, Oxford University Press, Oxford.

Swan, A. (2016), "Seven work ethic commandments for an entrepreneur", Forbes, 5 October, https://www.forbes.com/sites/andyswan/2016/10/05/7-work-ethiccommandments-for-an-entrepreneur/\#7b3243554ce6 (accessed 21 March 2019).

The World Bank (2004), Responsible growth for the new millennium, The World Bank, Washington, DC.

Trencher, G., Yarime, M., McCormick, K. B., Doll, C. N. H., and Kraines, S. B. (2014), "Beyond the third mission: exploring the emerging university function of cocreation for sustainability", Science and Public Policy, Vol. 41 No. 2, pp. 151-179.

UBS/PWC (2018), "Billionaires report 2018”, https://www.ubs.com/global/en/wealthmanagement/uhnw/billionaires-report.html (accessed 21 March 2019).

United Nations (1998), "Kyoto Protocol to the United Nations Framework Convention on Climate Change", https://unfccc.int/resource/docs/convkp/kpeng.pdf (accessed 21 March 2019).

Vleuten, E. van der, Oldenziel, R., Davids, M., and Lintsen, H. (2017), Engineering the future, understanding the past: a social history of technology, Amsterdam University Press, Amsterdam.

Weil, D. N. (2013), Economic growth, 3rd edn., Pearson, Harlow, UK. 
West, D. M. (2018), The future of work: robots, Al, and automation, Brookings Institute Press, Washington, DC.

Wikipedia (n. d.), "School strike for climate", available at https://en.wikipedia.org/wiki/School strike for climate (accessed 21 March 2019).

Wilson, C., Callister, M. and Seipel, M. (2018), "Everything is not Pleasantville: reframing public relations encroachment as work group autonomy in higher education", Public Relations Journal, Vol. 11 No. 3, pp. 1-22.

Woirol, G. R. (1996), The technological unemployment and structural unemployment debates, Greenwood Publishing Group, Westport, CT.

Zubok, V. M. (2007), A failed empire: the Soviet Union in the Cold War from Stalin to Gorbachev, University of North Carolina Press, Chapel Hill, NC. 